\title{
Prediction of Soil Temperature at Various Depths Using a Mathematical Model
}

\author{
${ }^{* 1}$ OYEWOLE, JA; ${ }^{1}$ OLASUPO, T; ${ }^{1}$ AKINPELU, JA; ${ }^{2}$ FABORO, EO \\ ${ }^{I *}$ Department of Physics and Solar Energy, ${ }^{2}$ Department of Industrial Chemistry \& Chemistry, Bowen University, Iwo \\ *Corresponding Author Email: joeademola@gmail.com
}

\begin{abstract}
This study discusses variation of soil temperature with depth using mathematical models at Ataoja School of Science, Osogbo, Osun State, Nigeria. Average conditions were assumed. The annual soil temperature cycles were modeled with fairly good accuracy. Differences in measured and predicted soil temperatures were determined at annual levels at depths $0 \mathrm{~cm}$ (top soil), $10 \mathrm{~cm}, 30 \mathrm{~cm}$ and $50 \mathrm{~cm}$. For the annual cycle, the absolute errors ranged from $0.5^{\circ} \mathrm{C}$ to $7.8^{\circ} \mathrm{C}$ with an average of $2.7^{\circ} \mathrm{C}$ at the soil surface $(0 \mathrm{~cm})$. At the $10 \mathrm{~cm}$ depth, the errors ranged from $0.1^{\circ} \mathrm{C}$ to $4.5^{\circ} \mathrm{C}$ with an average value of $2.0^{\circ} \mathrm{C}$. At the $30 \mathrm{~cm}$ depth, the absolute errors ranged from $0.05^{\circ} \mathrm{C}$ to $2.9^{\circ} \mathrm{C}$ with an average of $1.7^{\circ} \mathrm{C}$. The highest average absolute error was $2.7^{\circ} \mathrm{C}$ while the lowest average absolute error was $1.7^{\circ} \mathrm{C}$.
\end{abstract}

\section{DOI: https://dx.doi.org/10.4314/jasem.v22i9.09}

Copyright: Copyright (C) 2018 Oyewole et al. This is an open access article distributed under the Creative Commons Attribution License (CCL), which permits unrestricted use, distribution, and reproduction in any medium, provided the original work is properly cited.

Dates: Received: 09 January 2018; Revised: 10 August 2018; Accepted: 15 August 2018

Keywords: Soil temperature, transient heat flow, simulation, homogenous.

To enhance agricultural operations and food production in the country, good prediction techniques are needed for adequate monitoring of soil temperature variations. Soil temperature is one of the most critical factors that influence important physical, chemical and biological processes in soil and plant science. Soil hydraulic properties are affected by soil temperature (Bachmann, et al. 2002). Bacterial growth and plant production are both strongly temperature dependent, so also are organic matter decomposition and mineralization. Soil temperature affects plant growth first during seed germination, although seeds of different plants vary in their ability to germinate at low temperatures, all species show a marked decrease in germination rate in soils with low surface temperatures (Russell, 1973). The germination rate will increase significantly with temperature up to a certain point, above which the rate falls off again. Since rapid seed germination ensures an early crop, the temperature of the soil thus has a major influence on when various growth stages will occur. Metabolically regulated plant processes, such as water and nutrient uptake can be diminished below optimum rates at both low and high temperatures, resulting in temperature dependent yield patterns. (William J, and Roberts H, 2004). Soil temperature plays an important role during the life cycle of the plants right from germination, root extension and emergence of the reproductive stage (Fahim, et al. 2008) Scientists use soil temperature data in the research on variety of topics including climate change. (Sharatt et al, 1992).
Soil temperature is not one of the easily measured parameters. In cases where the soil temperature data are available, it's found to be incomplete and unsorted. Predictive methodologies based on acceptable principles could provide a solution to this problem. Some earlier works in this area have been done, e.g, Penrod, et al (1960) studied the temperature variation of sod-covered soil at Lexington, Kentucky from 1952 - 1956. Toy et al (1978) predicted mean monthly soil temperature solely from mean monthly air data, using simple linear models. These authors acknowledged that more elaborate models could be developed with the inclusion of soil variables. Gupta et al (1981) developed a predictive model for temperatures of bareand residue - covered soil using daily maximum and minimum air temperatures, initial soil temperature and thermal diffusivity profiles as inputs. This model simplified an earlier work (Gupta et al, 1981) by replacing measured hourly air temperature by an estimate, which was a function of the daily maximum and minimum air temperature. Ogunlela, (2003).

\section{MATERIALS AND METHODS}

The method employed in this study is an empirical model. In this study, certain assumptions were made. Some of these assumptions were that soil was homogeneous, the thermal diffusivity was constant and the heat flow was one dimensional. Under these conditions the pertinent heat equation is (Penrod et al (1960), Hillel, (1980) 


$$
\frac{\partial \mathrm{T}}{\partial t}=\alpha \frac{\partial^{2} \mathrm{~T}}{\partial^{2} t}
$$

Subject to the following conditions

Initial $\mathrm{t}=\mathrm{t}_{\mathrm{o}}$ and $\mathrm{T}=\mathrm{T}_{\mathrm{m}}$

$T=T_{m}+A_{o} \sin \left[\frac{2 \pi}{p}\left(t-t_{o}\right)\right]$

Boundary: $\mathrm{z}=0, \mathrm{t}=\mathrm{t}_{\mathrm{o}}$

Where: $\mathrm{T}=$ temperature; $\mathrm{t}=$ time; $\mathrm{Z}=$ depth; $\alpha=$ thermal diffusivity; $K_{\mathrm{T}}=$ thermal conductivity; $\rho=$ density; $c=$ heat capacity; $\mathrm{T}_{\mathrm{m}}=$ mean temperature; $\mathrm{t}_{\mathrm{o}}$ $=$ is the 'zero point' indicating the time the soil surface temperature first equals the mean temperature.

A solution to equation (1) is (Penrod et al, 1960, Hillel, 1980)

$$
T_{z, t}=T_{m}+A_{z} \sin \left[\frac{2 \pi}{P}\left(t-t_{o}\right)-\gamma z\right]
$$

Where: $\mathrm{T}_{\mathrm{z}, \mathrm{t}}=$ soil temperature at depth $\mathrm{z}$ and time $\mathrm{t} ; \mathrm{A}_{\mathrm{z}}$ $=$ amplitude of temperature wave at depth $\mathrm{z} ; \mathrm{A}_{\mathrm{o}}=$ amplitude at the soil temperature; $\mathrm{p}=$ period

$$
\begin{aligned}
& A_{z}=A_{0} e^{-\gamma z} \\
& \gamma=\sqrt{\frac{\pi}{\alpha p}}
\end{aligned}
$$

From equations (3) and (4),

$$
T_{z, t}=T_{m}+A_{0} e^{-\gamma z} \sin \left[\frac{2 \pi}{p}\left(t-t_{o}\right)-\gamma z\right]
$$

Study Area: Osogbo (Longitude $4^{\circ} 58 \mathrm{E}, 7.83^{\circ} \mathrm{N}$ ), the study area is located in the rain forest region of Nigeria. The precise study location was Ataoja, a town located in Osogbo, Nigeria. Average conditions were assumed in the simulations. A loamy soil was also used with thermal diffusivity $\alpha$, estimated as $5.00 \times 10^{-}$ ${ }^{3} \mathrm{~cm}^{2} / \mathrm{sec}\left(18.0 \mathrm{~cm}^{2} / \mathrm{hr}\right.$ ) (Hillel, 1980). Data of soil temperature from 2011-2012 (at depths $0 \mathrm{~cm}, 10 \mathrm{~cm}$, $30 \mathrm{~cm}$ and $50 \mathrm{~cm}$ ) were obtained from a data logger named "Hoboware data logger" installed at the station. The overall mean temperature was estimated as $\mathrm{T}_{\mathrm{m}}=$ $28.806^{\circ} \mathrm{C}$.

Figure 1 shows a plot of the temperature means, with amplitude $3.4^{\circ} \mathrm{C}$. For the annual temperature cycle, the period $\rho$ : 1 year $=365$ days $=8760$ hours. The time parameter was estimated from figure 1 as $t_{0}=15$ days $=360 \mathrm{hrs}$. Substituting appropriate values into equation (5). The subscript "a" denotes the annual cycle.

$$
\begin{aligned}
& \gamma_{a}=\sqrt{\frac{\pi}{\alpha p}}=\sqrt{\frac{\pi}{(18)(8760)}}=\sqrt{1.9923 * 10^{-5}}= \\
& 0.00446 \mathrm{~cm}^{-1}
\end{aligned}=
$$

The damping depth, d, a characteristic depth for the propagation of the temperature wave in the soil, is the depth at which the temperature amplitude decreases to the fraction 1/e of the amplitude at the soil surface $A_{0}$. It is expressed as

$$
d=\frac{1}{\gamma} \ldots \ldots \ldots \ldots(7) \quad(\text { Hillel, 1980). }
$$

Thus, the damping depth for the annual temperature variation for the study area (Osogbo) is

$$
d_{a}=\frac{1}{\gamma_{a}}=\frac{1}{0.00446}=224.215 \mathrm{~cm} \sim 224 \mathrm{~cm}
$$

The amplitude of the annual temperature wave at depth $\mathrm{z}$ is given from equation (4), as;

$$
A_{z_{a}}=3.4 e^{-0.00446 z}
$$

Where $A_{z_{a}}$ is in ${ }^{\circ} \mathrm{C}$ and $\mathrm{z}$ is in $\mathrm{cm}$. Thus, from equation (6) for the annual temperature

$$
\begin{aligned}
& T_{z, t}=28.806+3.4 e^{-0.00446 z} \sin \left[\frac{2 \pi}{8760}(t-\right. \\
& 360)-0.00446 z] . .(9)
\end{aligned}
$$

Variation, where $\mathrm{T}_{\mathrm{z}, \mathrm{t}}$ is in ${ }^{\circ} \mathrm{C}, \mathrm{z}$ in $\mathrm{cm}, \mathrm{t}$ in hours. The argument of the sine function is expressed in radians. Equation (9) could be used to determine the soil temperatures at various depths for any day of the year.

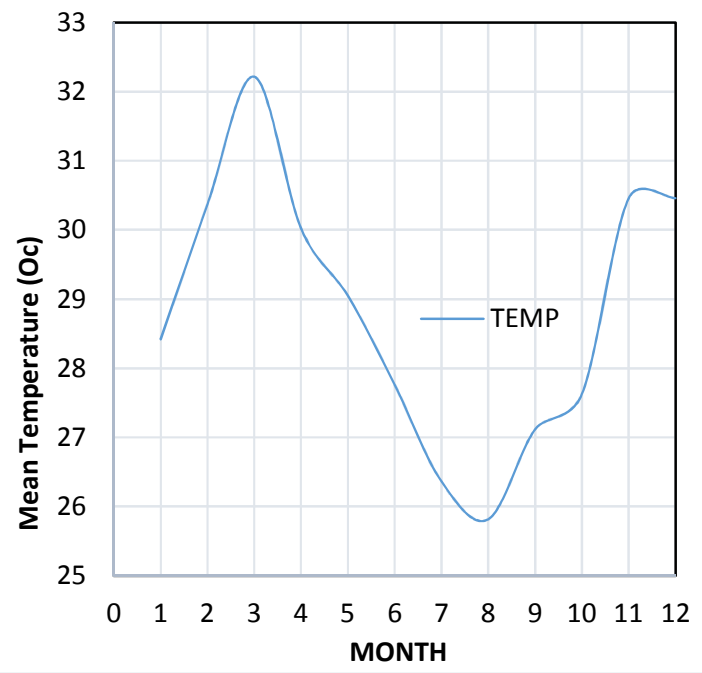

Fig 1: Ata-Oja, Osogbo temperature means in ${ }^{\circ} \mathrm{C}$ (2011-2012) 


\section{RESULTS AND DISCUSSION}

The measured and predicted soil temperatures at different depths for the annual cycle are shown in figures 2-5. For the annual cycle, the absolute errors ranged from $0.5^{\circ} \mathrm{C}$ to $7.8^{\circ} \mathrm{C}$ with an average of $2.7^{\circ} \mathrm{C}$ at the soil surface $(0 \mathrm{~cm})$. At the $10 \mathrm{~cm}$ depth, the errors ranged from $0.1{ }^{\circ} \mathrm{C}$ to $4.5^{\circ} \mathrm{C}$ with an average value of $2.0^{\circ} \mathrm{C}$. At the $30 \mathrm{~cm}$ depth, the absolute errors ranged from $0.05^{\circ} \mathrm{C}$ to $2.9^{\circ} \mathrm{C}$ with an average of $1.7^{\circ} \mathrm{C}$. At the $50 \mathrm{~cm}$ depth, the absolute error ranged from $0.02^{\circ} \mathrm{C}$ to $5.5^{\circ} \mathrm{C}$ with an average of $2.8^{\circ} \mathrm{C}$. The lowest average absolute error $\left(1.7^{\circ} \mathrm{C}\right)$ was recorded at the $30 \mathrm{~cm}$ depth and the highest average absolute error $\left(2.8^{\circ} \mathrm{C}\right)$ at the $50 \mathrm{~cm}$ depth. These results indicate a reasonable close agreement between measured and predicted soil temperatures. Of practical importance is the ability to predict soil temperatures at different depths for any specific day of the year. Equation (9) could be used for this purpose.

The damping depth is indicative of the extent of penetration of temperature wave into the soil profile. For the study area (Ataoja, osogbo), the damping depth for the annual cycle is $224 \mathrm{~cm}$.

Table 1: The parameter estimates for annual temperature cycle.

\begin{tabular}{|c|c|}
\hline PARAMETERSA & ANNUAL CYCLE \\
\hline PERIOD,,$\cdots($ HOURS) $a$ & 87600 \\
\hline TIME & $360=$ \\
\hline$\gamma \cdot\left(\mathrm{cm}^{-1}\right)-($ from equation & 0.00446 \\
\hline TH & \\
\hline
\end{tabular}

It can be seen from the figure 1 that the average temperature vary with the months of the year and became more apparent during the dry and wets seasons. We have high temperature means between November to March (dry season) and low temperature mean between April and October (wet season)

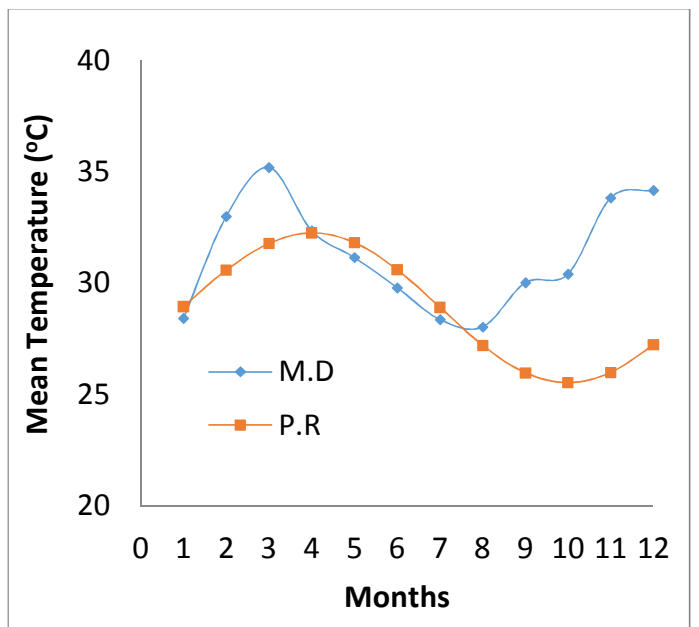

Fig 2: Graph showing average Measured and Predicted soil temperature for the top soil

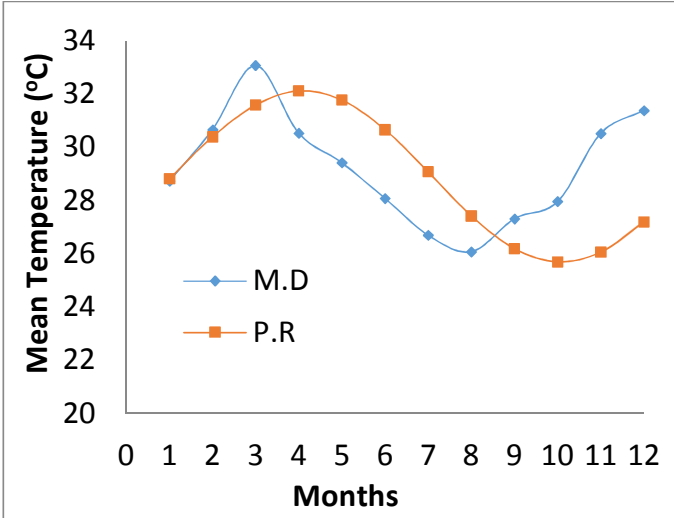

Fig 3: Graph showing average Measured and Predicted soil temperature for $10 \mathrm{~cm}$ depth

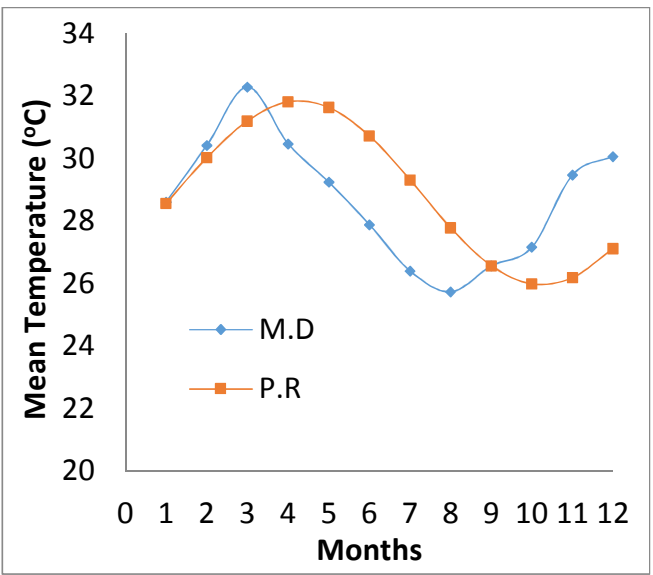

Fig 4: Graph showing average Measured and Predicted soil temperature at $30 \mathrm{~cm}$ depth.

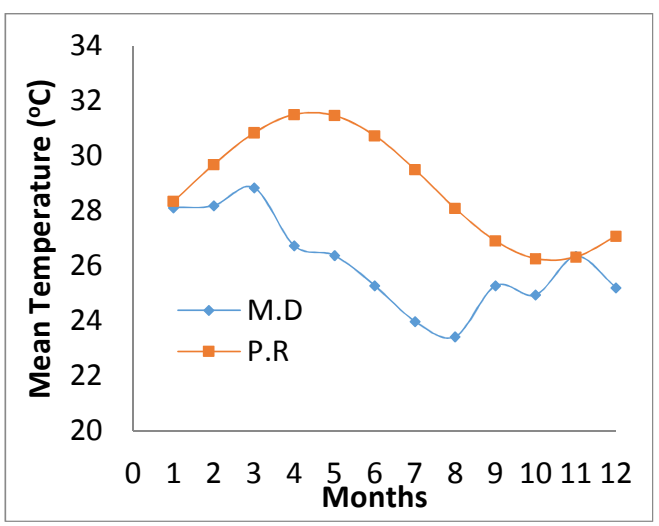

Fig 5: Graph showing average Measured and predicted soil temperatures at $50 \mathrm{~cm}$ depth.

Conclusion: Soil temperature variations ( with depth and time) were modeled using transient heat flow principle with the assumptions that the heat flow was one dimensional, the soil was homogeneous and that the thermal diffusivity was constant. The Predictive equations obtained can be used to affirm the suitability 
of any crop whose performances at different temperature conditions are known, which could lead to increase crop yield.

\section{REFERENCES}

Bachmann, J; Horton, R; Grant, SA; van der Ploeg, RR (2002). Temperature dependence of water retention curves for wet-table and water repellant. Soil Sci. Soc. Amer. J. 66 (1) p44-52

Fahim Ahmad, M; Ghulam, R (2008). Prediction of soil temperature using Air temperature: A case study for Faisbaland. Pakistan J. Meteorology. 5(9); 19-27

Gupta, S.C; Radke, RK; Larson, WE. (1981). "Predicting temperature of bare and residuecovered soils with and without a corn crop. Soil Sci. Soc. Am. J. 45(2); $405-412$.

Hillel, (1980). Fundamentals of Soil Physics. Academic Press; New York.
Ogunlela, A.O, (2003). Modelling Soil Temperature Variations .J. Agric. Res. Develop. 2(1)

Penrod E. B, J.M Elliot and W.K Brown (1960). Soil temperature Variation (1952-1956) at Lexington, Kentucky. Soil Sci. Issue 5. Pp.275-283

Russell, C (2006). 'Heat and mass transfer' $3^{\text {rd }}$ edition, S. Chand and company limited 13-15

Toy, T.E, G.R Foster, and K.G Renard (1978) "The prediction of mean monthly soil temperature from mean monthly air temperature," Soil Sci. 126, 96104.

van Bavel, CHM; Hillel, DI (1976) "Calculating potential and actual evaporation from a bare soil surface by simulation of concurrent flow of water and heat," Agric. Meteorol. 17(6), 453

William J, and Robert H., (2004). Soil Physics. Sixth edition,. John Wiley \& Sons Inc; 161-200 